The foregoing analysis of Hobbs leads to the following conclusions: (1) "Property" includes all wage demands. (2) Violence and striking and probably picketing constitute the requisite coercive activity. Where the coercive activity is fundamentally violent which may include a sitdown strike or a mass picket, Title Two affords no protection for wage demands. Where the coercive activity is peaceful striking or picketing for wage demands involving a "labor dispute" under the Norris-LaGuardia Act, Title Two provides a safeguard, except perhaps for a strike against the government. A "labor dispute" requires proof merely of a bona fide offer to work. (4) It is uncertain whether "wrongful" requires proof of unlawfulness under "criminal laws of the United States or of any State or Territory." It is clear however that a criminal rather than a tortious, intent is necessary for a conviction. Some precedents indicate that criminal intent is established when "wrongful" means are proved, regardless of the objective involved. Adoption of this theory would permit a conviction in the Local 807 situation and satisfy the apparent intent of Congress; but it also might require an extortion conviction where present employees engage in a sitdown strike or mass picketing or a strike against the government for a reasonable wage increase. Moreover, it overlooks the fact that Congress chose extortion as its weapon. Extortion is a compound felony and therefore requires proof of a felonious intent which will not be implied merely because the means are wrongful. Traditional robbery and extortion precedents are of little aid in discerning what is felonious intent in the coerced employment situation. A definition in terms of the featherbedding sanctions of the Lea and Taft-Hartley Acts is inappropriate in light of the legislative history surrounding Hobbs. Therefore, it seems reasonable to conclude that a bona fide offer to work negates criminal intent although the work is unnecessary to efficient operation by the employer, even though this conclusion gives no effect to the omission of the wage provisos after the 807 case.

\title{
THE TAXABILITY OF PUNITIVE DAMAGES
}

The Sixteenth Amendment conferred upon Congress the power "to lay and collect taxes on incomes, from whatever source derived" without apportionment among the states. ${ }^{1}$ The Amendment does not define what constitutes "income," nor is there much assistance to be had from the statutes enacted pursuant thereto. ${ }^{2}$ Thus the problem of supplying meaning

1. U.S. Const. Amend. XVI.

2. Net income is described in the Internal Revenue Code as "gross income computed under section 22, less the deductions allowed by section 23." INT. REv. CoDE \$21. Section 22 states: "Gross income' includes gains, profits, and income derived from salaries, wages, or compensation for personal service . . of whatever kind and in whatever form paid, or from professions, vocations, trades, businesses, commerce, or sales, or dealings in property, whether real or personal, growing out of the 
to the word has devolved upon the courts. In an early case the Supreme Court defined "income" as the gain derived from labor, from capital, or from both combined, and also the gain from the sale or conversion of capital assets. ${ }^{3}$ By applying this definition to punitive damage recoveries the courts have ruled that they do not constitute taxable income. The purpose of this Note is to re-examine this definition of taxable income and to determine the validity of its application to punitive damages. ${ }^{4}$

The Formulation of a Concept of Taxable Income.-The definition of "income" varies according to the purpose for which the term is to be employed, and varies as much among economists themselves, as it does between economists, accountants, or lawyers on the one hand, and laymen on the other..$^{5}$ The difficulty experienced by the economists in attempting to formulate a definitive concept of income for economic as well as tax purposes, ${ }^{6}$ suggested the size of the task confronting the Supreme Court in interpreting the meaning of "income" under the Sixteenth Amendment. In the leading case of Eisner v. Macomber, the Court tried to avoid the problem by refusing to "enter into the refinements of lexicographers or economists," 7 and adopted what it believed was a definition of income "as used in common speech":

" 'Income may be defined as the gain derived from capital, from labor, or from both combined,' provided it be understood to include profit gained through a sale or conversion of capital assets. . . ." 8

Placing great emphasis upon the words "derived from," the Court ruled that a mere increment in economic value is not sufficient to give rise to taxable income. Basically, therefore, the Macomber definition sets forth two factors which must be present for a receipt to constitute taxable income. First, the economic value must arise from one of the three possible

ownership or use of or interest in such property; also from interest, rent, dividends, securities, or the transaction of any business carried on for gain or profit, or gains or profits and income derived from any source whatever." INT. REv. CoDE $\$ 22(\mathrm{a})$. Other sub-sections of $\$ 22$ exclude certain items from gross income.

3. Eisner v. Macomber, 252 U.S. 189 (1920).

4. Throughout this Note no distinction will be made as to the source from which the punitive damages are received. From whatever source derived, punitive damages represent economic value to the recipient and it is immaterial for purposes of taxation whether they arise from statutory or common law causes of action.

5. Magiri, Taxable Incone 223-4 (Rev. ed. 1945).

6. A comprehensive treatment of the various concepts of income advanced by American economists may be found in Wueller, Concepts of Taxable Income II: The Annerican Contribution, 53 PoL. Scr. Q. 557 (1938).

7. Merchants' Loan \& Trust Co. v. Smietanka, 255 U.S. 509, 519 (1920). But see Rottschaefer, The Concept of Income in Federal Taxation, 13 MINN. L. REv. 637 (1929) ("It was to be expected that economic analysis would enter into the process, but at the same time that it would not be the sole factor in it.").

8. Eisner. v. Macomber, 252 U.S. 189, 207 (1920). The first pronouncement of this definition of "income" appears in Stratton's Independence v. Howbert, 231 U.S. 399,415 (1913), in which the Court was interpreting the Corporation Excise Tax Act of 1909 which measured the tax in terms of income to the corporation. 
sources named, and second, there must be a realization of an economic gain. ${ }^{9}$ By specifying the taxable income producing sources the Court, in effect, over-simplified the concept of income and at the same time unduly restricted it. The restrictiveness of the majority's decision was opposed by the four dissenters in two separate opinions. Justice Holmes stated briefly that income "should be read in 'a sense most obvious to the common understanding' at the time of its [the Sixteenth Amendment's] adoption." 10 Justice Brandeis also favored a broader interpretation of income, stating that "In terse, comprehensive language befitting the Constitution, they [the people of the United States] empowered Congress 'to lay and collect taxes on incomes, from whatever source derived.' They intended to include thereby everything which by reasonable understanding can fairly be regarded as income." 11

Most items which are normally considered "income" are covered by the specified sources of the Macomber definition. For this reason, the issue of realization has been before the courts more often than the issue of whether taxable income is produced from non-specified sources. ${ }^{12}$ There are items, however, which may be considered income, but for which the definition makes no provision.

Recovery of Damages as a Possible Source of Taxable Income.Damages recovered in a suit or compromise of damage claims are not classified by the Macomber definition as a possible source from which taxable income may arise. This by no means precludes the question of taxability of all such recoveries, since the courts have gone a step further and applied the test: "In lieu of what were the damages awarded?" 13 The application of this test may produce one of two results. The first is illustrated by the case of Hawkins v. Commissioner ${ }^{14}$ where the Board of Tax Appeals ruled that damages received in settlement of a pending suit for libel and slander did not constitute taxable income. The Board, although rejecting petitioner's claim that the damages did not fall within the Macomber definition, found that since they were compensation for a personal injury, they added nothing to the petitioner, "for the very concept which sanctions it [such compensation] prohibits that it shall include a profit." 15 The question of whether punitive or exemplary damages were taxable in-

9. There is no doubt that punitive damages are realized by the recipient. The only question presented is whether, under the Macomber definition, they are derived from a taxable source.

10. Eisner v. Macomber, 252 U.S. 189, 219-20 (1920).

11. Id. at 237 .

12. MAGILL, op. cit. supra note 5, at 175 . The Supreme Court has found that taxable income may be realized: in certain forms of corporate distributions; by settlors of trusts; by person exchanging property; by debtors from cancellation of debts; and by assignors who assign future income.

13. Raytheon Production Corp. v. Commissioner, 144 F.2d 110, 113 (1st Cir.), cert. denied, 323 U.S. 779 (1944).

14. 6 B.T.A. 1023 (1927).

15. Id. at 1025. 
come was reserved. ${ }^{16}$ This decision was in accord with earlier administrative opinions that damages received for injuries of such a personal nature were not taxable income. ${ }^{17}$ The case and the administrative rulings rest on the theory that since the economic value received is compensatory, in that it merely makes the injured party whole, no profit or gain is realized. By the same reasoning it has been held that damages which represent a replacement of lost capital or impairment of capital assets are not taxable. ${ }^{18}$

It does not follow, however, that all damages are not taxable income. A second result that is reached by applying the "in lieu of what" test is that damages for lost profits are taxable. Here the rationale is that if the lost profits had been earned they would have been taxable. ${ }^{19}$ The same result follows if the damages represent items other than profits which would have been taxable had they been received as other than damages. Thus damages for services rendered, ${ }^{20}$ damages paid for expenditures under a contract entered into for profits, ${ }^{21}$ and damages for loss of property in excess of its cost ${ }^{22}$ constitute taxable income. Punitive damages, however, do not fall within either of the results reached by the use of the "in lieu of what" test.

\section{Development of the Rule that Punitive Damages are not TAXABLE INCOME}

The rule that punitive damages do not constitute taxable income can be traced to two cases. In Farmers' and Merchants' Bank v. Commissioner ${ }^{23}$ it was held that damages received by the petitioner in compromising a pending suit for wrongful interference with petitioner's banking business were not taxable income. To determine whether the damages were taxable or not the court examined the fund in the light of the claim from which it was realized, and held that the damages were compensatory for the injury to the business. The fact that profits were used to determine the loss suffered did not control the disposition of the question as to whether the

16. $I d$. at 1024.

17. E.g., Sol. Op. 132, I-1 CuM. Bult. 92 (1922) ; I.T. 1852, II-2 Cum. Bull. 66 (1923). The same rationale was employed to hold that damages received for breach of promise to marry were not taxable income. Lyde McDonald, 9 B.T.A. 1340 (1928).

18. Durkee v. Commissioner, 162 F.2d 184 (6th Cir. 1947); Highland Farms Corp. v. Commissioner, 42 B.T.A. 1314 (1940).

19. United States v. Safety Car Heating \& Lighting Co., 297 U.S. 88 (1936); Commissioner v. Woods Machine Co., 57 F.2d 635 (1st Cir.), cert. denied, 287 U.S. 613 (1932); Armstrong Knitting Mills v. Commissioner, 19 B.T.A. 318 (1930); Swastika Oil \& Gas Co. v. Commissioner, 123 F.2d 382 (6th Cir. 1941), cert. denied, 317 U.S. 639 (1942).

20. Blease v. Commissioner, 16 B.T.A. 972 (1929) ; Buffalo Union Furnace Co. v. Commissioner, 23 B.T.A. 439 (1931).

21. Burnet v. Sanford \& Brooks Co., 282 U.S. 359 (1931).

22. See note 13 supra. Cf. Helvering v. William Flaccus Oak Leather Co., 313 U.S. 247 (1941) (fire insurance proceeds exceeding the cost or other basis, held, taxable income); see INT. REv. CoDE \$112(f).

23. 59 F.2d 912 (6th Cir. 1932). 
damages received were taxable."4 The court concluded that "One may be recompensed for an injury but it is a rare case in which one should have a profit out of it." 25 This idea that seldom is a profit realized out of an injury had its effect in the case of Central $R$. Co. of New Jersey $v$. Commissioner. ${ }^{28}$ There the taxpayer had initiated a suit against one of its former officers who had surreptitiously created a corporation with operations adverse to the taxpayer's interest. The officer had used his position as an officer of the taxpayer corporation to the advantage of his own organization and to the detriment of the taxpayer. By settlement of the suit the taxpayer received property valued at approximately $\$ 456,405$. This sum was not reported as income by the taxpayer in its return. After the Board of Tax Appeals had determined that it should have been reported, the circuit court reversed on the ground that the property received could not be traced to a "gain derived from capital, from labor, or from both "combined," nor could it be said to be a gain from a sale of a capital asset. The increment was found to be in the nature of a "windfall" being "a penalty imposed by the law on a faithless fiduciary, a gain granted gratuitously because of the necessity of keeping persons in positions of trust beyond the temptation of double dealing." 27 The court rejected the Commissioner's contention that the property was, in fact, a recovery of lost profits. $^{28}$ Although the opinion cited extensively from the case of Farmers' and Merchants' Bank, it did not consider whether this was the "rare case in which one should have a profit out of his injury."

The first case to rule specifically on the taxability of punitive damages was Highland Farms Corp. v. Commissioner. 29 Here the Board of Tax Appeals found that $\$ 90,000$ of a $\$ 100,000$ judgment was a return of capital, and that the balance constituted punitive damages. In overruling the Commissioner the Board held that the punitive damages were "neither for loss of capital nor for loss of profits," but were a penalty and as such did "not meet the test of taxable income set forth in Eisner v. Macomber. . . ."30 As authority for the proposition that a penalty imposed by law does not constitute taxable income, Central $R$. Co. of New Jersey was cited. ${ }^{31}$ The

24. Id. at 913. But cf. George DeLong Bailey et al., 12 P-H 1943 TC MEM. DEC. If 43,447 (1943) (taxpayer had sued for and recovered profits, recovery held taxable as profits). Where a pending suit is for loss of profits and damage to capital and it is amicably settled, there being insufficient evidence upon which to allocate the recovery, the courts hold the entire recovery as profits. Armstrong Knitting Mills, 19 B.T.A. 318 (1930); Arcadia Refining Co., 9 P-H 1940 BTA MEM. DEC. I 40,416 (1940), aff'd 118 F.2d 1010 (5th Cir. 1941); Martin Bros. Box Co., 12 P-H 1943 TC MEM. DEC. $\lceil 43,190$ (1943), aff'd mem., 142 F.2d 457 (6th Cir, 1944).

25. 59 F.2d 912,914 (6th Cir. 1932).

26. 79 F.2d 697 (3d Cir. 1935).

27. Id. at 699.

28. Ibid. The case has been criticized on the basis that the recovery was one of profits. See Sterling v. Commissioner, 93 F.2d 304, 306 (2d Cir. 1937), cert. denied, 303 U.S. 663 (1938); Lyeth v. Hoey, 96 F.2d 141, 143 (2d Cir.), rev'd on other grounds, 305 U.S. 188 (1938).

29. 42 B.T.A. 1314 (1940).

30. Id. at 1322 .

31. Ibid. 
punitive damages were not labelled a "windfall"; nor did the Board consider whether this was the "rare case" in which an injured party is recompensed for his injury and also makes a profit out of it, but summarily disposed of the issue of whether these damages were taxable income on the basis of the Macomber definition.

The question of whether sums received in settlement of punitive damage claims are taxable was brought before the Tax Court in the recent case of Glenshawe Glass Co. v. Commissioner. ${ }^{32}$ In this case the court stated: "It has long been established that punitive damages do not meet the test of taxable income set forth in Eisner v. Macomber [citing both the Central R. Co. and the Highand Farms Corp. cases]. . . . This basic definition [of income] has been recently cited with complete approval in Commissioner v. Culbertson, 337 U.S. 733, 740, and has been adhered to by the respondent in his Regulations 111, section 29.22(a)-1. Therefore, on the authority of those cases, we follow this rule of long standing that has never been questioned in any court and hold that sums received in settlement of the punitive damages claims do not constitute taxable income." 33

\section{Recent Developments}

This "rule of long standing" was seriously questioned by the Court of Claims in the recent case of Park \& Tilford Distillers Corp. v. United States ${ }^{34}$ and was invclved in two subsequent Tax Court cases. In Park \& Tilford the issue was whether the profits of an inside trader which were recovered by the corporation (by operation of $\S 16(b)$ of the Securities Exchange Act of $1934^{35}$ ) constituted taxable income to the corporation. In holding these receipts taxable, the court found that they were "income derived from any source whatever,' unless those words, as used in the statute, have a meaning more restricted than their apparent meaning," and to the plaintiff's argument that the receipts were a windfall and therefore not taxable, the court answered:

"It was, to be sure, a 'windfall' to the plaintiff. If Congress were to select one kind of receipt of money which, above all others, would be a fair mark for taxation, it might well be 'windfalls.' That would not penalize industry nor discourage enterprise or economy as taxes on wages, salaries and profits do. At any rate we cannot imagine Congress expressly exempting windfalls from taxation as income, as it has done expressly with regard to gifts and inheritances. . . ." 36

32. 18 T.C. 860 (1952), nonacquiesced in 1953 INT. Rev. BuLL. No. 3 at 1 (1953) (appeal pending before $3 \mathrm{~d}$ Circuit).

33. Id. at 868. But of. Rutkin v. United States, 343 U.S. 130 (1952).

34. 107 F. Supp. 941 (Ct. Cl. 1952), cert. denied, 73 Sup. Ct. 728 (1953).

35. 48 StaT. 896 (1934), 15 U.S.C. §78p(b) (1946).

36. Park \& Tilford Distillers Corp. v. United States, supra note 34 , at 942 . It has been suggested that a justification for not taxing punitive damages, particularly in the anti-trust area, is that this will discourage persons from instituting such suits for the game will not be worth the shot. Whether the question of the taxability of the puni- 
Plaintiff had also advanced the argument that the receipts did not fall within the Macomber definition of income, but the court was "unwilling to surmise that the [Supreme] court intended by this language, not necessary to its decision, to read out of the income tax statute language which Congress must have inserted with great deliberation and for important reasons, viz., 'income derived from any source whatever.' "37 Not only did the court limit the Macomber definition to cases involving stock dividends or analogous problems, but it also stated that "Cases such as Central R. Co. of New Jersey v. Commissioner . . Highland Farms Corporation . . . which seem to rest only upon the definition of income given by the Supreme Court in Eisner v. Macomber do not seem to us persuasive." 38 Although the narrow holding of the case is that recoveries under $\$ 16(\mathrm{~b})$ of the Securities Exchange Aict are taxable income to the corporation, the language employed by the court indicates that it would hold all "windfalls" to be taxable income to the recipients except those expressly excluded by Congress. Since the courts have labelled punitive damages "windfalls," this case suggests that they too are taxable income.

The Tax Court, however, in General American Investment Co., ${ }^{39}$ which involved the same factual situation presented in the Park \& Tilford case, while adopting the conclusion of the Court of Claims that recoveries of inside traders' profits are taxable income to the corporation, ${ }^{40}$ rejected the implication that such a holding would reverse the punitive damage cases. The court did not spell out its reason except to state that a different factual situation was present in the latter cases. A few weeks later the Tax Court handed down its decision in William Goldman Theatres, ${ }^{41}$ wherein the petitioner had recovered a judgment of $\$ 375,000$, of which $\$ 125,000$ was reported as recovery of lost profits. The balance was not reported at all because it represented punitive damages awarded by operation of $\S 4$ of the Clayton Act. A deficiency was determined by the Commissioner who contended, in the alternative, that the punitive damages recovered were "income" under $\S 22(\mathrm{a})$, or that the total damages recovered represented lost profits and were therefore subject to taxation. The court, however, held that the balance of $\$ 250,000$ represented a penalty, and as such was not taxable income. It felt bound to follow the Glenshaw

tive damages recovered enters into the calculations of a party considering bringing such a suit is very speculative. However, the possibility of recovering losses sustained in the past and enjoining the violator from future acts seems to far outweigh the question of the taxability of the punitive damages that would be received.

37. Id. at 943.

38. $I d$. at 945 .

39. CCH TAX CT. REP. $\llbracket 19,372$ (T.C. 1952) (appeal pending before $2 d$ Circuit).

40. This decision was reviewed by the whole court with three judges concurring on the ground that the profits referred to under $\S 16(\mathrm{~b})$ of the Securities Exchange Act "were income of the petitioner within the words and intention of section 22(a) since they were 'profits' either from 'sales or dealings in property . . . growing out of the ownership of ... or interest in such property' or 'from any source whatever." (Italics added). 1953).

41. CCH TAX CT. Rep. $\llbracket 19,401$ (T.C. 1953) (time for appeal expires June 25, 
Glass Co., the Central R. Co., and the Highland Farms cases until they were specifically overruled or until Congress enacted legislation to tax punitive damages. In attempting to distinguish its previous case of General American Investment $C_{o}$., the court said that the petitioner there did not receive punitive damages but recovered profits "pursuant to a statute which provided that certain profits realized by corporate insiders under circumstances there present should 'inure to and be recoverable by' the corporation." 42 This distinction between the recoveries under $\$ 16(\mathrm{~b})$ of the Securities Exchange Act and the punitive damages recovered under $\S 7$ of the Sherman Act or $\S 4$ of the Clayton Act is tenuous. In both cases, the amount of recovery is determined arbitrarily. Under $\$ 16(\mathrm{~b})$ the amount of the recovery is not the "net profit" realized by the insider in any true sense of the word, but is an amount computed by determining the difference between the lowest-priced purchases and the highest-priced sales of the corporation's stock within the six months' period before and/or after the dates of the insider purchases and sales. ${ }^{43}$ The amount computed in this fashion would rarely be equal to the "profit" as commonly understood, that the trader actually realized. Under $\S 4$ or $\S 7$ the amount of recovery is arbitrarily set by allowing treble damages. Furthermore, the court's distinction fails to take into account the fact that in both cases the element of a penalty is present. The recovery in the Central $R$. Co. case, which was labelled a "penalty" comes very close to being the same type recovery involved under $\$ 16(\mathrm{~b})$. 44 Legal writers have intimated that the recoveries under $\S 16(b)$ are a form of penalty imposed because of a breach of fiduciary duty. ${ }^{4 \overline{5}}$ Also, the Tax Court has determined that the inside

42. Ibid.

43. This method of determining the amount the corporation may recover is in accordance with the rule set forth in Smolowe v. Delendo Corp., 136 F.2d 231 (2d Cir.), ceri. denied, 320 U.S. 751 (1943).

44. Compare Smolowe v. Delendo Corporation, supra note 43, at 239 ("We must suppose that the statute was intended to be thorough-going, to squeeze all possible profits out of stock transactions, and thus to establish a standard so high as to prevent any conflict between the selfish interest of a fiduciary officer, director, or stockholder and the faithful performance of his duty.") with Central R. Co. of New Jersey v. Commissioner, 79 F.2d 697, 699 (3d Cir. 1935) ("It was a penalty imposed by the law on a faithless fiduciary, a gain granted gratuitously because of the necessity of keeping persons in positions of trust beyond the temptation of double dealing.").

In opposing the petition for certiorari to the Supreme Court by Park \& Tilford, the United States argued that the Central $R$. Co. case was incorrectly decided, that its rationale has been rejected, and that regardless of whether its facts were distinguishable from those of the Park \& Tilford case, the "alleged conflict does not require resolution by this Court." (Brief for United States in opposition to certiorari, pp. 10-11). This argument overlooks the fact that the punitive damage cases are based primarily on the rationale advanced in the Central $R$. Co. case and that the Park \& Tilford case is in conflict with this rationale. The United States evidently was willing to settle for half a victory rather than take the chance of losing the Park \& Tilford case. But see 1953 INT. REV. BULL. No. 9 at 2 (1953) (treasure trove ruled taxable income by the Commissioner).

45. Cook and Feldman, Insider Trading Under the Securities Exchange Act, 66 HARV. L. REV. 385, 408 (1953); Yourd, Trading in Securities by Directors, Officers and Stockholders: Section 16 of the Securities Exchange Act, 38 Mrcr. L. Rev. 133, 150 (1939) ("The recovery under the statute smacks more of being in the nature of a penalty paid for having entered in a forbidden transaction. . . "). But see Darrell, The Tax Treatment of Payments under Section 16(b) of the Securities 
trader cannot deduct the payment he has made to the corporation under $\S 16$ (b) because it is a penalty. ${ }^{46}$ Under close analysis, therefore, it is seen that there is only one difference between the $\S 16(\mathrm{~b})$ and the punitive damages recoveries-the degree of severity of the penalty.

\section{The INAPplicability of EIsNer v. Macomber}

All of the cases holding that punitive damages are not taxable income have rested primarily upon the Macomber definition as to the possible sources from which taxable income can be realized. However, there are three reasons why the phrase "income from whatever source derived" should not be interpreted to mean merely the gain from the three possible sources set forth in Macomber.

The Semantics of Macomber.-The courts when carrying Macomber forward have seemingly applied it as an all-inclusive definition. A closer examination of the language in the Macomber case indicates, however, that the named sources were not intended to be all-inclusive. Immediately after setting forth the definition, the majority opinion stated that: "Brief as it is, it indicates the characteristic and distinguishing attribute of income essential for a correct solution of the present controversy." 47 Thus, the quoted definition may be said to be nothing more than dictum in the case. ${ }^{48}$ In fact, the Eisner v. Macomber statement as to what is income has been characterized as a "generalization rather than a definition." 49 Furthermore, the Court must have realized that an all-inclusive definition could not be promulgated. Only a few years before the Macomber case, Justice Holmes, in construing the word income, made his classic statement that: "A word is not a crystal, transparent and unchanged, it is the skin of a living thought and may vary greatly in color and content according to the circumstances and the time in which it is used." ${ }^{50}$ Eleven years after Macomber, the Court again referring to a definition of income, declared in United States v. Kirby Lumber Co. that: "We see nothing to be gained by the discussion of judicial definitions." 51 These statements raise a caveat against

Exchange Act of 1934, 64 HaRv. L. Rev. 80, 90-91 (1950) ("The recovery under this section appears, in some respects, to be more of a penalty for engaging in an undesirable transaction than compensation for an injury. . . . On the other hand, Section 16(b) ... merely takes the profit out of certain prescribed transactionswithout adding anything as a penalty. . . ."); Report of the Securities Exchange Commission on Proposals for Amendments to the Securities Act of 1933 and the Securities Exchange Act of 1934, H.R. Doc., 77th Cong., 1st Sess. 38 (1941).

46. William F. Davies, Jr., 17 T.C. 549 (1951); William L. Dempsey, 20 P-H 1951 TC MEM. DEC. $\$ 51,281$ (1951).

47. Eisner v. Macomber, 252 U.S. 189, 207 (1920) (Italics added).

48. See Park \& Tilford Distillers Corp. v. United States, supra note 34, at 943. There was little doubt that returns from invested capital constituted taxable income, but the major issue in Eisner v. Macomber was whether a return in the form of a stock dividend constituted a realization of taxable income to the recipient.

49. Surrey and Warren, The Income Tax Project of the American Law Institute: Gross Income, Dednctions, Accounting, Gains and Losses, Cancellation of Indebtedness, 66 Harv. L. Rev. 761, 770 (1953).

50. Towne v. Eisner, 245 U.S. 418, 425 (1918).

51. 284 U.S. 1,3 (1931). 
employing the Macomber definition as an all-inclusive one as is done in the case of punitive damages. Professor Magill contends that the latter statement by Justice Holmes does not indicate an abandonment of a "definitive concept of taxable income" by the Court, but an abandonment of the process of deciding cases by "deduction from the brief and cryptic definition advanced in Eisner v. Macomber." 52 The deduction, however, is the very process the courts have employed to determine whether punitive damages are taxable income. Professor Magill's conclusion has been borne out in most instances, since there has been a tendency for the Court to limit the Macomber case to its narrow holding (a common stock dividend to a common stockholder is not taxable income) and to related problems of corporate distributions. ${ }^{53}$ There are no reasons why the deductive process should continue to be used to determine the taxability of punitive damages.

Macomber in Disrepute.-The Court has repeatedly declared that Congress intended to use its taxing power under the Sixteenth Amendment to its full extent.54 In Brushaber v. Union Pacific R.R.55 it declared that the extent of Congress' power is "exhaustive and embraces every conceivable power of taxation" subject to the limitations that direct taxes be apportioned and that indirect taxes be uniform; and further, that the Sixteenth Amendment did not "purport to confer power to levy income taxes in a generic sense-an authority already possessed . . . but that the whole purpose of the Amendment was to relieve all income taxes when imposed from apportionment. . . " 56 Therefore, under the Sixteenth Amendment the only limitation upon Congress' power to tax income would seem to inhere in the word "income." Since the Supreme Court has indicated an unwillingness to be limited by a judicial definition, ${ }^{57}$ and because of the difficulty experienced in attempting to trace certain gains to the Macomber sources, the courts have in borderline cases tended toward a broader approach in interpreting the income statute-one in terms of any economic gain not expressly excluded by the income tax statute. In a few cases taxable income was found to have arisen from the operation of the taxpayer's business without an attempt to trace it to the Macomber sources. One example of this appears in Helvering v. Bruun, where the Supreme Court held that the taxpayer gained taxable income from the forfeiture of a leasehold upon which the tenant had erected a new building. ${ }^{58}$ The

52. MAGILL, op. cit. supra note 5 , at 443.

53. Magill, op. cit. supra note 5, at 80; Notes, 45 HARv. L. Rev. 1072 and n.3 (1932); 38 VA. L. REv. 789 (1952).

54. Southern Pacific Co. v. Lowe, 247 U.S. 330, 337 (1918) ; Eisner v. Macomber, 252 U.S. 189, 203 (1920); Irvin v. Gavit, 268 U.S. 161, 166 (1925); Helvering v. Stockholms Enskilda Bank, 293 U.S. 84, 89 (1934); Douglas v. Willcuts, 296 U.S. 1,9 (1935).

55. 240 U.S. 1 (1916).

56. Id. at 12, 17-18. Accord, Stanton v. Baltic Mining Co., 240 U.S. 103 (1916); Peck \& Co. v. Lowe, 247 U.S. 165 (1918).

57. See text at note 51 sitpra.

58. 309 U.S. 461 (1940). 
taxpayer contended that the acquisition of the building was an accrual of value "due to extraneous and adventitious circumstances." 59 In rejecting this contention, the Court stated:

"The respondent can not successfully contend that the definition of gross income in $\S 22(a)$ of the Revenue Act of 1932 is not broad enough to embrace the gain in question. That definition follows closely the Sixteenth Amendment. . . .

"While it is true that economic gain is not always taxable as income, it is settled that the realization of gain need not be in cash derived from the sale of an asset. Gain may occur as a result of . . . other profit realized from the completion of a transaction. . . .

"Here, as a result of a business transaction, the respondent received back his land with a new building on it, which added an ascertainable amount to its value." 60

Another example of this tendency toward a broader approach is found in Chicago R.I. \& P. Ry. v. Commissioner. ${ }^{61}$ The unreported items in question here consisted of overcharges resulting from errors in computing passenger fares and claims against the petitioner which were never collected by those entitled to them. The taxpayer contended that they did not constitute taxable income because they did not fall within the Macomber definition. In rejecting this contention the Court of Appeals for the Seventh Circuit said that:

"A practical mind (and problems of taxation are eminently practical ....) would have some difficulty in accepting the conclusion that passengers' overpayments, received and retained by petitioner, were not income derived from its business." 62

In both of these cases, although the courts might have been able to trace the gain to one of the Macomber sources, that approach was not used. $^{63}$ Instead, the gain was found to have been realized from the operation of a business and that fact was deemed sufficient to hold the gains taxable. In both cases the taxpayer advanced the argument that the gains were not traceable to the Macomber sources, and in each case the court rejected that argument and employed the broader approach, i.e., gains realized in the course of operation of a business. Also, in the Park $\&$ Tilford case the Court of Claims not only adopted the broader approach, but indicated that it would not follow the Macomber definition. In fact, the Park \& Tilford

59. $I d$. at 467 .

60. Id at $468-9$. It should be noted that Congress subsequently reversed the law on this point by enacting $\$ 22(\mathrm{~b})(11)$ which is discussed infra at note 68 .

61. 47 F.2d 990 (7th Cir. 1931).

62. Id. at 992 . The same reasoning was applied to hold the uncollected claims taxable income to the taxpayer.

63. Compare Rutkin y. United States, 343 U.S. 130 (1952) with Commissioner v. Wilcox, 327 U.S. 404 (1946). 
case comes close to declaring that all economic gain not expressly excluded by Congress is taxable.

The difference in approach is that in the punitive damage cases the courts examine the nature of the transaction, label the gain as a windfall, and then look to the Macomber definition to determine its taxability. In the other cases the courts examine the nature of the transaction and then look to the statute to determine if the language employed in the statute is broad enough to cover the transaction in question. Since the courts by looking to the nature of the gain realized and the income tax statute, have recognized that taxable income may arise from sources other than those specified in the Macomber definition, there is nothing to prevent them from applying the same approach to the punitive damage cases.

The difficulties encountered by the restrictiveness of the Macomber definition ${ }^{64}$ can be avoided by employing an approach in terms of any economic gain not expressly excluded by the income tax statute. However, this approach, like the Macomber definition, if followed to its logical conclusion would involve as many difficulties. There is no doubt that a person who paints his own house, grows his own food, or performs innumerable personal services for himself realizes an economic gain. Under the proffered approach the question of taxability of such economic gains would not depend upon whether or not they are income; but upon considerations of administrative convenience in extending the tax to such items, the amount of tax that would be realized in view of the high cost of collection, and public policy.

Statutory Inconsistency.-Assume that income for purposes of taxation is to be defined as the gain derived from the three sources set forth in the Macomber definition. What effect does such a construction of the word "income" have in interpreting the other provisions of $\$ 22$ ? Section 22(b) excludes from gross income certain items. Gifts, bequests, devises, and inheritances are specifically excluded from gross income under $\S 22(\mathrm{~b})(3) .^{65}$ It is clear that these items do not arise from labor, capital, or conversion of a capital asset. The same applies to $\S 22(\mathrm{~b})(5)^{66}$ which excludes compensation for injuries or sickness and $\S 22$ (b) (11) ${ }^{67}$ which excludes the gain from improvements made by the lessee on the lessor's property realized upon the termination of forfeiture of the lease. ${ }^{68}$ Why should these items

64. The general dissatisfaction with the Macomber definition as to income producing sources is reflected in the changes suggested in the American Law Institute's Federal Income Tax Project discussed infra at note 70 et seq. See also Surrey and Warren, suppa note 49 , at $769-775$.

65. INT. Rev. CODE $\$ 22$ (b) (3).

66. INT. REv. CoDe $\$ 22(\mathrm{~b})(5)$.

67. IN'. Rev. CoDE \$22(b) (11).

68. This provision was enacted into the Code by Congress two years after the Supreme Court rendered its decision in Helvering v. Bruun, 309 U.S. 461 (1940). The Supreme Court has two approaches in interpreting the Internal Revenue Code which are illustrated by this case and those dealing with alimony. In Helvering v. Brinn, the Court extended the statute and Code to cover improvements by a lessee upon a lessor's property and Congress expressly overruled the Court's decision within two 
be specifically excluded if "income" is limited to the three sources of the Macomber definition? Although these sections may be said to have been inserted for the purpose of clarification and to make certain that the courts give a general provision, such as $\S 22(a)$, a particular meaning, nevertheless, until Congress specifically limits the general provision the courts should give it full effect. These illustrations, at least, tend to show that "income derived from any source whatever" has a broader meaning than that given to it by the Macomber definition.

\section{A Suggested Approach and Legal Bases for Taxing Punitive Danages}

The apparent abandonment of the deductive process by the Supreme Court in United States $v$. Kirby Lumber Co. ${ }^{69}$ indicates the need for a new approach to determine what constitutes taxable income. The American Law Institute, in its Federal Income Tax Project, recommends that the present language of $\S 22(\mathrm{a})$, i.e., "all gains, profits, and income," be retained. The Institute hopes that by enumerating certain inclusions and exclusions, and by applying a case by case determination for the unforeseen situations, a combination of "wide inclusiveness and elasticity" will result. ${ }^{70}$ However, this suggested approach leaves much to be desired, since the list of inclusions in many instances retains the word "income" which is basically what is to be determined. ${ }^{71}$ For example, $\S \mathrm{X} 105$ (b) (3) provides that "[i] ncome from a business" is to be included as gross income. Are punitive damages recovered by a business organization "income" from a business? The Institute does not answer this question. A possible answer may be found in other sections. Under $\S \mathrm{X105(b)(16):} \mathrm{"Income} \mathrm{from}$ damages, including recoveries by suit, settlement, or otherwise, subject to section $\mathrm{X} 107(\mathrm{~d})$ and (e)" is taxable. ${ }^{72}$ The comment to this section recognizes that "Reparation for some kinds of harm . . . is excluded from treatment as gross income," citing as an example the C.A. Hawkins case, and directs the reader to "consider Central Railroad Company of New

years. In the alimony cases the Court ruled that alimony was not taxable income to the divorced wife. After a series of cases dealing with alimony arrangements in various states Congress was forced to take up the question. By enacting $\S 22(\mathrm{k})$ into the Code on Oct. 21, 1942, Congress eventually settled the question of both the deductibility of alimony payments by a divorced husband and the taxability of alimony to the divorced wife. In the William Goldman Theatres case, counsel for the taxpayer successfully contended that the alimony approach be utilized and the Tax Court refused to consider punitive damages as taxable until Congress enacts specific legislation declaring them to be taxable or until the earlier cases are overruled by a high authority. It is submitted that as a matter of expediency the Bruun case approach be utilized and have Congress, in view of the broad language of $\$ 22(a)$, later exclude any items which it has not specifically considered and which it believes should not be taxable.

69. 284 U.S. 1 (1931). See text at note 51 et seg., supra.

70. A.L.I., Fejeral Income Tax Statute, Comments §X105 (Tent. Draft No. $6,1952)$.

71. A.L.I., Federal Income Tax Statute $\$ \S X 105$ (b) (3), X105(b) (7), X105 (b) (8), X105(b) (10), X105(b) (11), X105(b) (12), X105(b) (13), X105(b) (15), X105(b) (16), X105(b) (18) (Tent. Draft No. 6, 1952).

72. Id. at $\S \mathrm{X} 105(\mathrm{~b})(16)$. 
Jersey v. Comm'r. . . ."73 However, in excluding certain compensatory damages in respect to injury, sickness, or other personal harm in $\S \mathrm{X107}(\mathrm{e})$, the Institute, in the comment, reaches the conclusion that since punitive damages are not compensatory they are not excluded by this section and are taxable. ${ }^{74}$ Therefore, punitive damages would be taxable under $\S \mathrm{X} 105(\mathrm{~b})(16)$ in cases of recoveries connected with personal injuries, but not when recovered in connection with business. The Institute would leave the question of taxing business recoveries of punitive damages for "full development" by the judiciary. ${ }^{75}$ The effect of the Institute's approach is to reduce the area of interpretation from the broad language of $\S 22$ (a) of the Internal Revenue Code to an interpretation of each of the items listed for inclusion. But in each case the interpretation would center upon the crucial word "income."

Extensive alterations as suggested by the American Law Institute are not necessary for the solution of the immediate problem of this Note. Once the courts free themselves of the Macomber definition and begin to think in terms of any economic gain realized which is not expressly excluded, they should have little difficulty holding punitive damages taxable to the recipient on either of two possible legal bases. First, there is sufficient language in $\S 22$ (a) for such a holding. In the case of punitive damages recovered by any business organization they can be said to fall within the language of $\S 22(a)$ as the "gains . . . of whatever kind . . . from . . . businesses, commerce . . . or dealings in property . . . growing out of the ownership or use of or interest in such property. . . ."76 Punitive damages are a gain to the recipient; they arise from business or commerce, and also out of dealings or interests in property, for only if some property or property right has been damaged will they be awarded. This is, in effect, the approach taken in Brum and Chicago R.I. \& P. Ry. ${ }^{77}$ It is more difficult, however, to find a legal basis in the statute upon which to tax punitive damages recovered by an individual arising out of a personal injury. But the basis for such a holding might be that since $\$ 22(\mathrm{~b})$ (5) only excludes recoveries for personal injuries which are received as compensation for such injuries, ${ }^{78}$ and since punitive damages are not compensatory, by implication such damages must be included within the phrase "income derived from any source whatever." A logical result of this argument will be that punitive damages arising from personal injuries will not be taxable whenever they are awarded to compensate the injured party for damages incapable of ascertainment. ${ }^{79}$

73. A.I.I., Frderal Income TaX Statute, Comments $\$$ X105, comment 4 (Tent. Draft No. 6, 1952).

74. Ia. at $\$ \mathrm{X} 107(\mathrm{e})$.

75. Id. at $\S \mathrm{X} 105$.

76. INT. Rev. Code $\$ 22(a)$.

77. See text at note 58 et seq., supra.

78. INT. Rev. CODE $\$ 22(b)(5)$.

79. See text at note 17 supra. 
Another legal basis can be found in the cases which have held that recoveries for capital injuries in excess of the cost of the capital loss are taxable. ${ }^{80}$ Although one of the reasons advanced for not taxing punitive damages is that it is a rare case where a person makes a profit or a gain out of his injury, these decisions indicate that a person can make a gain or a profit if there is an injury to capital. By analogy it can be said that punitive damages are the excess of the actual damages suffered and therefore taxable on the same basis as the recovery in excess of the capital loss. This would apply regardless of whether the punitive damages are considered a penalty or not. Although labelled punitive, these damages are sometimes awarded, in some jurisdictions, to compensate for those injuries which are "incapable of pecuniary estimate" ${ }^{81}$ and in others as a reward for bringing a wrongdoer to justice. ${ }^{82}$ Whether punitive damages be considered as the excess over the actual damages suffered, the recovery for damages which are incapable of ascertainment, or a reward for bringing a person to justice, the courts should consider whether they are not the case where an injured party makes a gain or profit out of his injury..$^{83}$

\section{Conclusion}

The experience of the courts over the past forty years shows the impossibility of formulating a definition of "income" which will satisfy the tax statute in all cases. Eisner v. Macomber did not attempt to formulate an all-inclusive definition and it is a misinterpretation of that case to read it as such. Furthermore, the apparent tendency to limit Macomber to its facts indicates that the decision should not be blindly followed in areas

80. See notes 13 and 22 sipra.

81. See cases cited in 25 C.J.S., Daraages $\$ 117$ n.99, 1, 2; 15 AM. Jur., Damages $\S 266$ n.2, 3, 4. In Mathey v. Commissioner, 10 T.C. 1099 (1948), aff'd, 177 F.2d 259 (1st Cir. 1949), the taxpayer had recovered a judgment in a patent infringement suit. The judgment included the amount of the actual damages proved at trial plus an increase of this amount by $50 \%$, which the trial court awarded the taxpayer to compensate him for the damages suffered which were difficult to prove. The full judgment recovered was held to be taxable income representing lost profits.

82. See cases cited in 25 C.J.S., Damages $\$ 117$ n.10; 15 Am. Jur., Daniages $\S 266$ n.15. Punitive damages under $\$ 4$ of the Clayton Act and $\$ 7$ of the Sherman Act, however, are considered a form of civil punishment. See William Goldman Theatres, Inc., supra note 41 , and cases cited therein.

83. Payments of penalties imposed by law are not deductible by the payor as part of his business expenses. Commissioner v. Longhorn Portland Cement Co., 148 F.2d 276 (5th Cir.), cert. deried, 326 U.S. 728 (1945); Universal Atlas Cement Co., 9 T.C. 971, aff'd mem., 171 F.2d 294 (2d Cir. 1948), cert. denied, 336 U.S. 962 (1949); Le Sage v. Commissioner, 173 F.2d 826 (5th Cir. 1949), reversing 16 P-H 1947 TC Mem. DEC. I 47,318 (1947). Taxing them to the payee may be claimed to amount to double taxation. However, since payments under $\$ 16(\mathrm{~b})$ of the Securities Exchange Act are not deductible by the payor (see note 58 supra), when the Court of Claims was pressed with this contention it stated: "We do not understand, however, that the fact that $A$, who pays money to $B$, cannot deduct the amount of the payment from his income in computing his income tax, has any direct bearing upon whether the receipt of the payment by $B$ is income to him. For example, if an employer pays wages or salaries in excess of those permitted by a wage stabilization law, and is therefore not entitled to charge them against his income as a business expense, that does not mean that they are not fully taxable to the employees who receive them." Park \& Tilford Distillers Corp. v. United States, supra note 34, at 944. This would also apply to punitive damages. 
completely divorced from the corporate distributions situations. The rule that punitive damages are not taxable is the result of the deductive process based on the Macomber definition. Since this process has been rejected by the courts in other cases there is no reason to revive it in the punitive damage cases. Freed of this restriction, the courts will be able to look to the nature of punitive damages and then determine their taxability in terms of the comprehensive language of $\$ 22$ (a). Legal bases for holding them taxable can be found either in existing case interpretations of the statute or by adopting the broader approach of taxing all realized gains which are not expressly excluded by Congress. Another legal basis could be found by analogy to the rule that recoveries of damages in excess of the cost of capital loss are taxable. The taxation of punitive damages is not without support on policy grounds. There are two good policy arguments for taxing punitive damages, namely: taxing them does not penalize initiative and industry as do taxes on wages, profits, and other commonly recognized income items; and, the general burden of taxation is more equitably distributed by including them within the phrase "income from whatever source derived." 